\title{
PENGARUH PEMAHAMAN BUSHU TERHADAP KEMAMPUAN MENGARTIKAN KANJI
}

\author{
Febi Ariani Saragih, Lavitta Yulia \\ Universitas Brawijaya, febiwahyusantoso@gmail.com \\ Universitas Brawijaya, lavittayulia17@gmail.com
}

\begin{abstract}
One of the difficulties of kanji learning is knowing the meaning of the kanji. This is a very vital thing because kanji is basically a symbol of meaning. Bushu is a kanji-forming factor that shows meaning. For this reason, this study wants to know the influence of bush $u$ understanding on the ability to interpret kanji (a combination of kanji). The theory used in the research is the theory of bushu and kanji. This study using ex post facto research with a quantitative approach. The instrument in this study using a test. The test questions that have been made, are used to determine the level of understanding of bushu on interpreting kanji in Japanese education students 2015. The results showed that the average understanding of bush $u$ respondents was 81.2. While the average understanding of bushu in interpreting the respondent's logo is 85.8. Based on the results of simple linear regression analysis, the magnitude of the influence of bushu understanding (X) on the ability to interpreting kanji $(\mathrm{Y})$ is $50.7 \%$. while the remaining $49.3 \%$ is influenced by other factors besides understanding bushu (X). The conclusion of the results of this study is there is a strong influence between understanding bushu on the ability to interpret the meaning of kanji.
\end{abstract}

Keywords: understanding, bushu, ability, kanji.

\section{PENDAHULUAN}

Hal yang menjadi kesulitan besar yang dialami oleh para pembelajar bahasa Jepang adalah huruf Jepang terutama kanji. Bagi pembelajar bahasa Jepang, kanji adalah suatu hal yang membingungkan dan sulit untuk dimengerti. Hal ini dirasakan terutama oleh mahasiswa yang tidak memiliki latar belakang budaya kanji seperti pembelajar dari Indonesia, tetapi dalam bahasa Jepang kanji adalah hal yang penting. Oleh karena itu, kesulitan yang dialami dan dirasakan bagi mereka di antara 3 huruf yang digunakan dalam bahasa Jepang adalah kanji.

Kanji bukanlah huruf melainkan gambar yang memiliki makna karena dia diciptakan berdasarkan makna yang ingin disampaikan (Takebe 1989:9). Misalnya kanji“川". Kanji ini dibaca "kawa" yang berarti sungai. Kanji ini diciptakan karena sungai mempunyai aliran yang jika digambarkan akan tampak 
seperti huruf ini. Atau kanji “月” yang dibaca “tsuki”. Kanji ini mempunyai arti "bulan" karena diciptakan merujuk bentuk bulan sabit.

Kanji terdiri dari beberapa coretan. Coretan-coretan ini membentuk bagian dasar pada sebuah kanji. Bagian dasar kanji tersebut akhirnya akan membentuk satu kanji yang dikenal dengan istilah radical atau bushu (Mitamura, 1997: 12). Melalui bushu, dapat mempermudah pembelajar dalam mencari arti maupun pengucapan suatu kanji di kamus. Kanji dengan bushu yang sama, sering memiliki arti yang sama atau mendekati.

Menurut pendapat Hamanishi dalam Renariah (2004:4), apabila kita mengetahui arti bushu dan menyatukan dengan bagian-bagian yang lain maka akan dapat mengarahkan dan memahami arti keseluruhan kanji. Melihat dalam kamus kanji, bushu yang melekat sebagian besar memiliki korelasi makna dengan suatu kanji. Contoh dari kanji yang berkorelasi makna dengan bushu-nya, ialah: ～$($ sanzui $)+$ 昜 $(y u)=$ 湯 $(y u)$. Menurut Kanehide (1987:551) Kanji tersebut menunjukkan suatu benda cair dengan suhu yang hangat, sehingga secara leksikal memiliki makna ,air panasee.

Berdasarkan pernyataan Tamamura (2001: 166), dari 9.353 kanji yang terdapat dalam Setsumon Jitaishōten, terdapat 540 bushu. Tetapi saat ini diatur menjadi 214 bushu. Bushu-bushu tersebut dikelompokan dalam tujuh macam bushu, yaitu hen, tsukuri, kanmuri, ashi, tare, nyoo, dan kamae.

Menurut Burhanuddin Alim (2014: 10) "Bushu adalah huruf yang berfungsi sebagai akar atau dasar dari mana huruf-huruf lain di bentuk. Bushu terbagi menjadi tujuh kelompok yang masing-masing kelompok terdiri atas beberapa jenis, yaitu : (1) hen, yaitu bushu yang berada sejajar di sisi kiri kanji; (2) tsukuri, yaitu bushu yang berada sejajar di sisi kanan kanji; (3) kanmuri, yaitu bushu yang berada atas dan memayungi kanji; (4) ashi, yaitu bushu yang berada dibagian bawah dan menopang kanji. (5) tare, yaitu bushu yang berbentuk siku

171 | http://journal.unesa.ac.id/index.php/paramasastra 
denan posisi terbalik dan memayungi kanji; (6) nyoo, yaitu bushu yang berbentuk siku dengan posisi normal dan memangku kanji; bushu yang terbentuk siku dengan posisi normal dan memangku kanji; dan (7) kamae, yaitu bushu yang melingkungi atau mengapit kanji.

Dalam pembelajaran kanji terdapat tiga unsur penting yang dikenal dengan istilah kei-on-gi (形音義) yaitu bentuk, cara baca, dan arti (Takebe, 1989:8). Dari segi makna atau arti, kanji relatif lebih mudah. Karena merupakan simbol makna, maka meskipun digunakan atau digabung dengan kanji lain, tidak menimbulkan perubahan arti. Dapat diketahui bahwa meskipun sebenarnya bentuk kanji ada banyak, cara penulisan yang rumit, serta cara baca yang juga banyak, tetapi karena arti atau maknanya cenderung sama, sebetulnya merupakan kemudahan tersendiri dalam mempelajarinya. Kembali lagi ke konsep awal bahwa kanji adalah simbol makna, maka mengetahui maknanya lebih penting dari pada membaca atau menulis kanji.

Bagian-bagian dari kanji jika kita melihat bentuk kanji dapat diketahui bahwa ada kanji yang bentuknya sederhana, ada juga yang rumit. Ada yang terdiri dari satu kanji serta ada yang terdiri dari gabungan dua atau lebih kanji. kanji yang terdiri dari satu huruf biasanya menjadi bushu dari kanji. Dalam sebuah kanji tersusun dari bushu dan onpu. Bushu adalah simbol makna/arti, sedangkanya опри adalah simbol bunyi (Kindaiichi, 2001:85).Misal kanji “語”.Kanji ini memunyai bushu“言” yang berarti “bicara”, sedangkan “吾” adalah onpu (simbol bunyi) yang dibaca "go".

Dari paparan di atas, dapat diketahui bahwa untuk memudahkan pembelajar memahami arti kanji yang jumlahnya sangat banyak, maka diperlukan pemahaman bushu untuk memudahkan dalam mengingat arti kanji.

Metode yang digunakan dalam penelitian ini adalah metode ex post facto dengan pendekatan kuantitatif. Data digunakan untuk mengetahui seberapa jauh pemahaman bushu terhadap kemampuan mengartikan kanji pada mahasiswa 
Pendidikan Bahasa Jepang angkatan 2015. Sumber data dalam penelitian ini adalah soal test mengartikan bushu dan mengartikan kanji. Sedangkan sebagai data adalah nilai dari soal yang telah dikerjakan siswa. Populasi dalam penelitian ini adalah mahasiswa Program Studi Pendidikan Bahasa Jepang Universitas Brawijaya yang telah mengambil mata kuliah kanji 1 dan 2 sejumlah 40 orang. Dengan rincian 12 mahasiswa dari kelas A dan 28 mahasiswa dari kelas B. Kelas A digunakan sebagai uji validitas dan realibilitas, sedangkan kelas B digunakan sebagai sampel penelitian. Prosedur Penelitian dalam penelitian ini :

1. Menentukan materi untuk soal, yaitu dengan cara memilih kanji yang akan dijadikan soal. Kriterianya adalah bukan kanji yang hanya mempunyai satu unsur saja. Contoh kanji 金、木、日, kanji tersebut tidak termasuk objek kanji yang diujikan.

2. Membuat soal sesuai dengan tujuan penelitian yaitu soal tentang pemahaman bushu dan mengartikan kanji.

3. Uji validitas isi dengan bantuan validator.

4. Uji validitas dan realibilitas soal.

5. Mengujikan ke sampel

6. Menganalisis data

7. Menarik kesimpulan

Teknik pengumpulan data menggunakan tes untuk mengetahui pemahaman bushu dan seberapa besar pengaruh pemahaman bushu dalam mengartikan kanji pada mahasiswa Pendidikan Bahasa Jepang angkatan 2015. Materi soal-soal kanji diambil dari buku Minna No Ninggo I dan Minna No Ninggo II karena mahasiswa angkatan 2015 baru saja menyelesaikan pembelajaran dalam buku Minna no Nihongo I\&II. Teknik analisis data yang di gunakan dalam adalah metode kuantitatif. Untuk mengetahui berpengaruh atau tidaknya bushu terhadap kemampuan mengartikan kanji maka diuji melalui 
pengujian hipotesis secara parsial, dengan menggunakan Analisis Regresi Linier Sederhana. Menurut Joko Widiyanto (2012) Regresi Linear Sederhana adalah Metode Statistik yang berfungsi untuk menguji sejauh mana hubungan sebab akibat antara Variabel Faktor Penyebab (X) terhadap Variabel Akibatnya.

\section{PEMBAHASAN}

Dari uji validitas diketahui dari 58 soal yang diujikan, semua soal dinyatakan valid. Soal dikatakan valid apabila nilai hitung lebih besar dari nilai tabel dengan taraf signifikan $5 \%$ atau $1 \%$ untuk $n=9$. Taraf signifikan untuk $n=9$ adalah sebesar 0,602 untuk 5\% dan 0,521 untuk 1\%. Setiap butir soal yang valid akan diberikan tanda $(*)$ atau (**). Seperti yang dapat dilihat pada lampiran 3, pada lampiran tersebut dapat dilihat soal tersebut mendapat tanda (*) atau (**). Semua butir soal diujikan terdapat nilai $(*)$ atau $(* *)$, maka semua soal dikatakan valid. Hasil perhitungan reliabilitas pada lampiran diketahui bahwa nilai Alpha Cronbach pada romawi I 0,992 dan romawi II 0,993 . Soal dikatakan reliabel apabila nilai $\alpha>r$ tabel. Nilai $r$ tabel dengan $n=9$ adalah sebesar 0,602 . Jadi yang berarti semua soal tersebut dikatakan reliabel atau terpercaya sebagai instrumen pengumpulan data penelitian.

Tabel 1. Hasil Test Pemahaman Bushu Terhadap Kemampuan Mengartikan Kanji

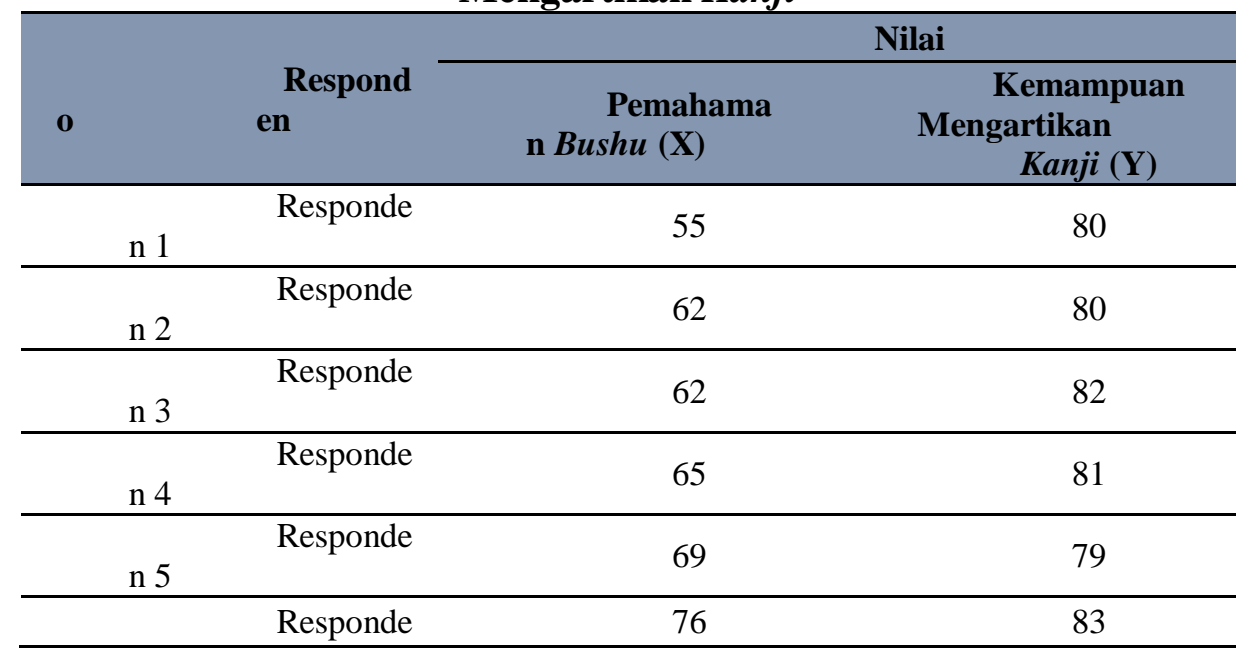


Febi Ariani Saragih dan Lavitta Yulia, Pengaruh Pemahaman Bushu... (hlm.170-183)

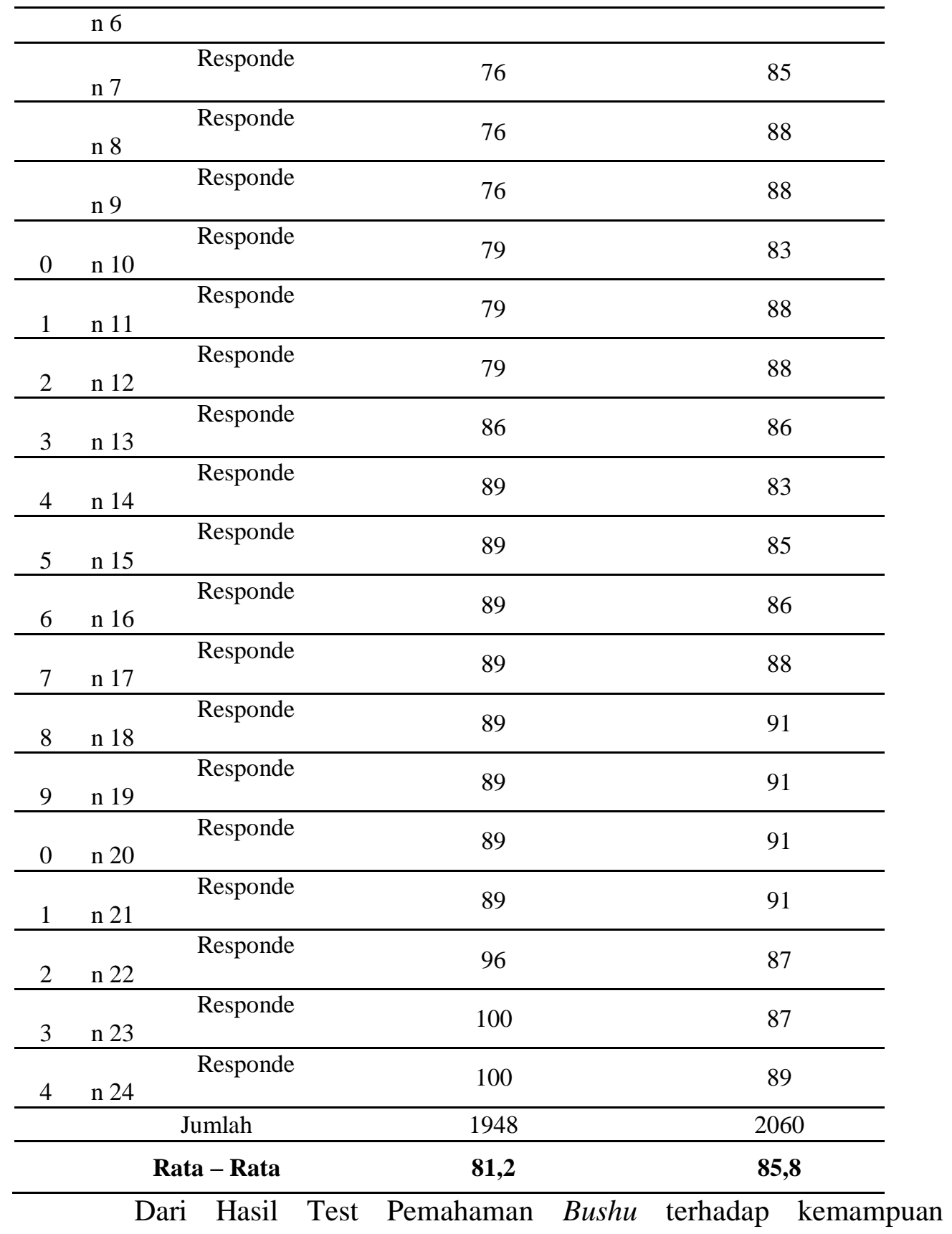

Mengartikan Kanji pada tabel 1 di atas, dapat diketahui bahwa rata-rata nilai dari test Pemahaman Bushu terhadap kemampuan Mengartikan Kanji adalah 85,8. Jika dilihat dari kriteria nilai, nilai tersebut termasuk dalam rentan nilai 80-100 yang 
berati mempunyai kritria dengan huruf A yaitu sangat baik. Dari 24 responden nilai terkecil adalah 79 dan 4 responden yang mendapatkan nilai tertinggi, yaitu 91.

Tabel 2. Statistik Deskriptif

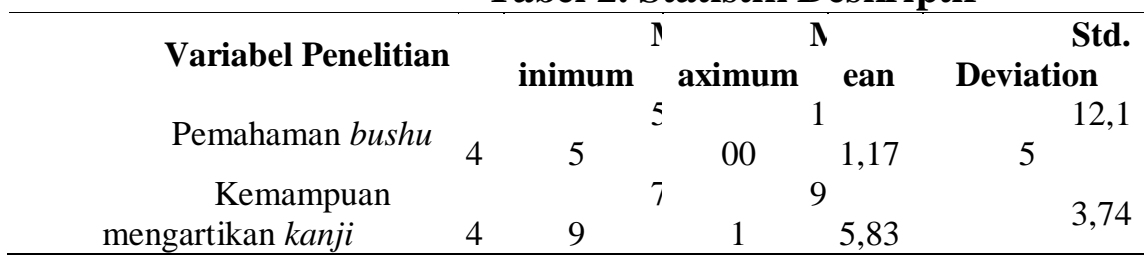

Statistik deskriptif pada variabel Pemahaman Bushu (X) diperoleh nilai minimum sebesar 55 dan nilai maksimum mencapai 100. Rata-rata variabel ini sebesar 81,17 dengan standart deviasi sebesar 12,15. Sedangkan pada variabel Kemampuan mengartikan kanji (Y) diperoleh nilai minimum sebesar 79 dengan nilai maksimum mencapai 91 . Rata-rata variabel ini sebesar 85,83 dengan standart deviasi sebesar 3,74.

Pemahaman bushu mahasiswa program studi pendidikan bahasa Jepang dapat diketahui berdasarkan test. Test bersebut merupakan test mencari arti bushu serta pengaruh bushu dalam mengartikan kanji. Hasil perolehan nilai test keseluruhan dapat diketahui rata-rata nilai keseluruhan test adalah 81,2. Nilai tersebut termasuk dalam kriteria nilai sangat baik. Dari 58 soal yang diberikan terdapat 29 pertanyaan mengenai pemahaman bushu dan 29 pertanyaan mengenai arti kanji.

Dari 29 pertanyaan mengenai pemahaman bushu yang diberikan kepada responden, kesalahan yang sering terjadi pada soal nomor 10, 11, 13, 20, 22, 23, 24, 26 dan 28. Contohya pada soal nomor 10 bushu” 禾(nogihen)”, bushu ini mempunyai arti "padi”. Namun sebagian responden salah dan menjawab dengan memilih jawaban "benang;kain tenun". Soal nomor 11 adalah bushu " 糸(itohen)” bushu ini mempunyai arti “benang; kain tenun”. Namun sebagian http://journal.unesa.ac.id/index.php/paramasastra | 176 
responden salah dan menjawab dengan memilih jawaban "rumput". Soal nomor 13 adalah bushu" ß (kozatohen)", bushu ini mempunyai arti "bukit; tanah". Namun sebagian responden salah dan menjawab dengan memilih jawaban "atap;bangunan". Soal nomor 20 adalah bushu “它kanmuri)" bushu ini mempunyai arti "tempat tinggal". Namun sebagian responden salah dan menjawab dengan arti "atap". Soal nomor 22 adalah bushu “へ(hitogashira)" bushu ini mempunyai arti "manusia". Namun sebagian responden salah dan menjawab dengan arti "atap;bangunan". Soal nomor 23 adalah bushu “竹(takekanmuri)"bushu ini mempunyai arti "bambu”. Namun sebagian responden salah dan menjawab dengan arti "padi”. Soal nomor 24 adalah bushu “+ (kusakanmuri)"bushu ini mempunyai arti "rumput". Namun sebagian responden salah dan menjawab dengan arti "pohon”. Soal nomor 26 adalah bushu “...(renga)" bushu ini mempunyai arti "api". Namun sebagian responden salah dan menjawab dengan "air”. Soal nomor 28 adalah bushu “之(shinnyoo)” bushu ini mempunyai arti "perpindahan". Namun sebagian responden salah dan menjawab dengan "perjalanan; bepergian".

Dari keseluruhan soal yang sering terjadi kesalahan, soal nomor 22 adalah soal yang paling sering terjadi kesalahan, dari 24 responden hanya 2 responden yang menjawab soal tersebut dengan benar. Secara bentuk, bushu “人(hitogashira)" terlihat mempunyai arti sesuatu yang berada di atas, contohnya "atap;tempat tinggal", namun arti yang sebenarnya adalah "manusia".

Tabel 3. Analisis Regresi Linier Sederhana

\section{Regression} Variables Entered/Removed $^{\mathrm{a}}$

\begin{tabular}{|c|c|c|c|}
\hline & Variables & Variables & Method \\
\hline del & Entered & Removed & \\
\hline
\end{tabular}




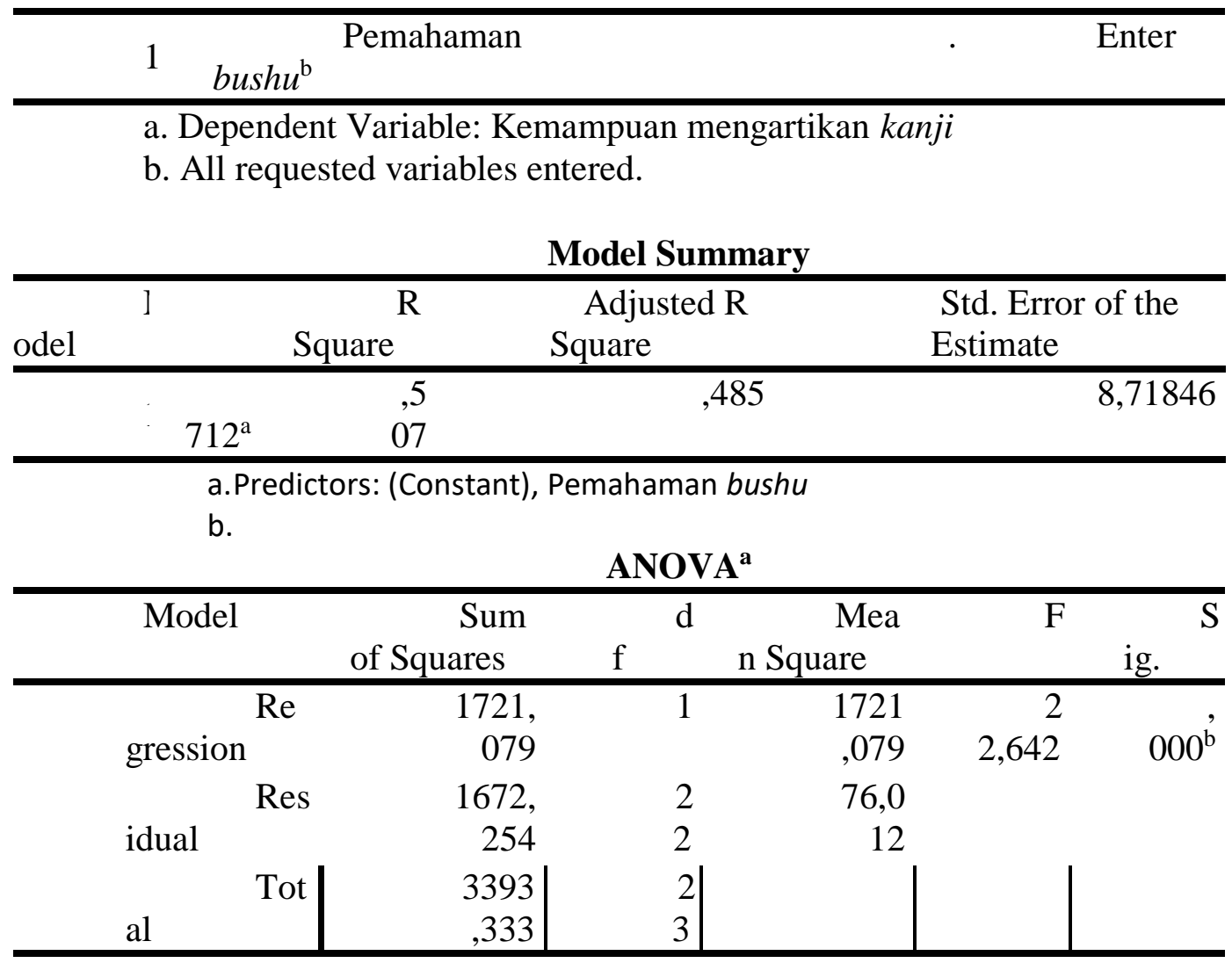

a. Dependent Variable: Kemampuan mengartikan kanji c. Predictors: (Constant), Pemahaman bushu

\section{Coefficients $^{\mathrm{a}}$}

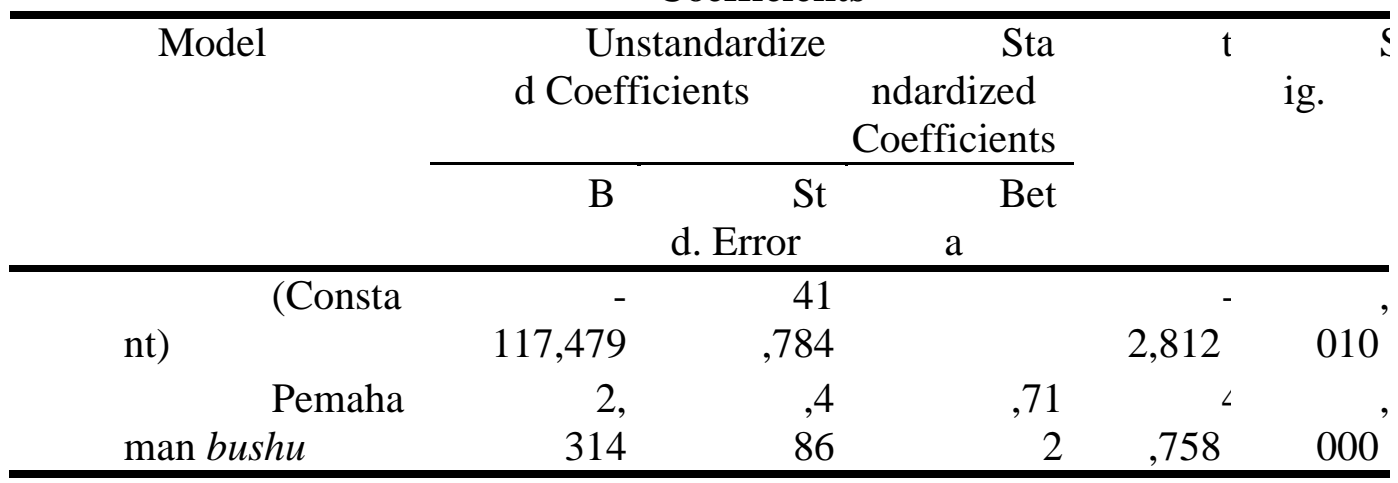


a.Dependent Variable: Kemampuan mengartikan kanji

Pengaruh pemahaman bushu terhadap kemampuan mengartikan kanji pada mahasiswa program studi pendidikan bahasa Jepang dapat diketahui berdasarkan Analisis Regresi Linier Sederhana . Analisis Regresi Linier Sederhana bertujuan untuk mengetahui atau menguji pengaruh satu variabel bebas atau variabel independent terhadap variabel terikat atau variabel dependent. Bila skor variabel bebas diketahui maka skor variabel terkaitnya dapat diketahui besarnya. Jika nilai signifikasi tidak lebih dari nilai probabilitas 0,05 , artinya variabel bebas berpengaruh secara signifikan terhadap variabel terikat, dan jika nilai signifikasi lebih dari nilai probabilitas 0,05 , artinya variabel bebas tidak berpengaruh secara signifikan terhadap variabel terikat. Dalam penelitian ini Identifikasi variabel bebas (X) adalah pemahaman bushu, sedangkan variabel terikat (Y) adalah kemampuan mengartikan kanji.

Kemampuan mengartikan kanji $=-117,479+2,314$ pemahaman bushu nilai Constant sebesar $-117,479$ merupakan nilai dari variabel Kemampuan mengartikan kanji apabila variabel Pemahaman Bushu (X) konstan (=0). Nilai koefisien regresi variabel Pemahaman Bushu (X) sebesar 2,314. Nilai ini menunjukkan peningkatan yang terjadi pada variabel Kemampuan mengartikan kanji apabila Pemahaman bushu (X) meningkat.

Berdasarkan nilai Fhitung sebesar 22,642 dengan nilai signifikansi sebesar 0,000. Nilai $F_{\text {tabel }}$ pada derajat bebas 1 dan 22 serta taraf nyata $5 \%$ sebesar 4,301. Karena nilai $F_{\text {hitung }}$ lebih besar dari $F_{\text {tabel }}$ atau nilai signifikansi lebih kecil dari taraf nyata 5\% maka disimpulkan terdapat pengaruh yang signifikan Pemahaman bushu (X) terhadap Kemampuan mengartikan kanji (Y).

Berdasarkan nilai $t_{\text {hitung }}$ sebesar 4,758 dengan nilai signifikansi sebesar 0,000 . Nilai tabel pada derajat bebas 22 dan taraf nyata $5 \%$ sebesar 2,074. Karena 
nilai thitung lebih besar dari tabel atau nilai signifikansi lebih kecil dari taraf nyata 5\% maka disimpulkan terdapat pengaruh yang signifikan Pemahaman bushu (X) terhadap Kemampuan mengartikan kanji (Y) dengan arah pengaruh yang positif. Artinya, semakin baik Pemahaman Bushu (X) maka Kemampuan mengartikan kanji akan semakin meningkat.

Berdasarkan hasil koefisien determinasi diperoleh koefisien korelasi (R) sebesar 0,712 artinya terdapat hubungan yang sangat kuat antara Pemahaman Bushu (X) dengan Kemampuan mengartikan kanji (Y). Koefisien determinasi $\left(\mathrm{R}^{2}\right)$ yang diperoleh sebesar 0,507 yang berarti Kemampuan mengartikan kanji (Y) dipengaruhi oleh Pemahaman Bushu (X) sebesar 50,7\%, sedangkan sisanya yaitu 49,3\% dipengaruhi oleh faktor lain selain Pemahaman Bushu (X).

Berdasarkan grafik garis regresi cenderung meningkat, hal ini dikarenakan pengujian pengaruh dan hubungan antara Pemahaman Bushu (X) terhadap Kemampuan Mengartikan Kanji (Y) bertanda positif, artinya semakin baik pemahaman bushu seseorang maka kemampuan untuk mengartikan kanji juga akan semakin meningkat dan sebaliknya semakin rendah pemahaman bushu seseorang maka kemampuan untuk mengartikan kanji akan semakin menurun. Berdasarkan hasil analisis, besarnya pengaruh Pemahaman Bushu (X) terhadap Kemampuan Mengartikan Kanji (Y) adalah 50,7\%.

Dari 29 pertanyaan mengenai pengaruh pemahaman bushu terhadap arti kanji yang diberikan kepada responden, kesalahan yang sering terjadi pada soal nomor $6,8,11,12,13,16,17,18,20$, dan 25. Soal nomor 6 adalah kanji "接 (setsu)", kanji ini mempunyai arti "sambung atau dekati". Namun sebagian responden salah dan menjawab dengan arti "tanda atau karcis". Soal nomor 8 adalah kanji "録 (roku)", kanji ini mempunyai arti “daftar atau catat". Namun sebagian responden salah dan menjawab dengan arti "sifat atau keadaan".

Soal nomor 11 adalah kanji " 館 (yakata)", kanji ini mempunyai arti "pemerintah;pegawai". Namun sebagian responden salah dan menjawab dengan http://journal.unesa.ac.id/index.php/paramasastra | 180 
arti “gedung;kantor". Soal nomor 12 adalah kanji ”廊 (rou)", kanji ini mempunyai arti "serambi". Namun sebagian responden salah dan menjawab dengan arti "bagian". Soal nomor 13 adalah kanji " 個 (ko)", kanji ini mempunyai arti "individu". Namun sebagian responden salah dan menjawab dengan arti “sifat;keadaan”. Soal nomor 16 adalah kanji”漫 (man)", kanji ini mempunyai arti "lucu atau olok - olok". Namun sebagian responden salah dan menjawab dengan arti“pancar atau mempertunjukkan”. Soal nomor 17 adalah kanji "律 (ritsu)", kanji ini mempunyai arti "irama atau atur". Namun sebagian responden salah dan menjawab dengan arti“rencana atau gambar". Soal nomor 18 adalah kanji "祖 (so)", kanji ini mempunyai arti "nenek moyang". Namun sebagian responden salah dan menjawab dengan arti“pedang”.

Soal nomor 23 adalah kanji ”縣 (agata)”, kanji ini mempunyai arti "gantung atau tangguh". Namun sebagian responden salah dan menjawab dengan arti“nenek moyang”. Soal nomor 27 adalah kanji ”駐 (chuu)”, kanji ini mempunyai arti "berada". Namun sebagian responden salah dan menjawab dengan arti“pintu atau hubungan”. Dari keseluruhan soal yang sering terjadi kesalahan, soal nomor 13 adalah soal yang paling sering terjadi kesalahan, dari 24 responden hanya 6 responden yang menjawab soal tersebut dengan benar.

Dari hasil penelitian juga ditemukan jawaban responden banyak menjawab dengan benar pada soal pemahaman bushu nomor 20ウ (ukanmuri) yang memiliki arti Tempat tinggal dengan soal kemampuan mengartikan kanji nomor 10寮 (ryou) yang memiliki arti asrama dan pada soal pemahaman bushu nomor 12車 (kuruma) yang memiliki arti kendaraan dengan soal kemampuan mengartikan kanji nomor 4輸 (yu) yang memiliki arti Angkut atau transportasi.

Dari analisis yang telah dilakukan peneliti, 7 dari 24 responden mengalami penurunan dikarenakan kurangnya pemahaman terhadap bushu yang 181 | http://journal.unesa.ac.id/index.php/paramasastra 
dinyatakan dengan hasil test pemahaman bushu terhadap mengartikan kanji. Dari hasil penelitian juga ditemukan jawaban yang 17 responden mengalami kenaikan banyak menjawab dengan benar dan dari pengambilan data juga ditemukan 6 responden yang dapat menjawab soal kanji dengan benar tanpa memahami bushu. Hal tersebut dapat terjadi apabila responden menghafalkan kanji dengan metode yang tidak menjadikan bushu dengan kunci utama dalam proses memahami arti kanji. Dari data yang diperoleh diketahui pemahaman bushu terhadap kemampuan mengartikan kanji sangat berpengaruh. Seperti yang dinyatakan oleh Mitamura (1997: 12) bahwa melalui bushu, dapat mempermudah pembelajar dalam mencari arti maupun pengucapan suatu kanji di kamus. Kanji dengan bushu yang sama, sering memiliki arti yang sama atau mendekati.

\section{SIMPULAN}

Dari paparan di atas dapat disimpulkan bahwa ada pengaruh yang kuat antara pemahaman bushu terhadap kemampuan mengartikan kanji. Hal ini diketahui dari:

1. Pemahaman bushu mahasiswa program studi pendidikan bahasa Jepang berdasarkan test pemahaman bushu yang terdiri dari 29 soal yang telah diberikan kepada responden dan mendapatkan hasil yang sangat kuat, yaitu 81,2. Dari 24 responden 2 responden mendapatkan nilai tertinggi 100 dan nilai terendah 55. Jadi pemahaman bushu mahasiswa program studi pendidikan bahasa Jepang sangat baik.

2. Pemahaman Bushu terhadap Kemampuan Mengartikan Kanji pada program studi pendidikan bahasa Jepang bertanda positif, artinya semakin baik pemahaman bushu seseorang maka kemampuan untuk mengartikan kanji juga akan semakin meningkat dan sebaliknya semakin rendah pemahaman bushu seseorang maka kemampuan untuk mengartikan kanji akan semakin menurun. Berdasarkan hasil analisis,ditemukan hasil koefisien Determinasi koefisien 
korelasi (R) sebesar 0,712 artinya terdapat hubungan yang sangat kuat antara Pemahaman Bushu (X) dengan Kemampuan mengartikan kanji (Y). Koefisien determinasi $\left(\mathrm{R}^{2}\right)$ yang diperoleh sebesar 0,507 yang berarti Kemampuan mengartikan kanji (Y) dipengaruhi oleh Pemahaman Bushu (X) sebesar 50,7\%, sedangkan sisanya yaitu 49,3\% dipengaruhi oleh faktor lain selain Pemahaman Bushu (X).

\section{DAFTAR PUSTAKA}

Alim, Burhanudin. 2014. Ayo Belajar Bahasa Jepang. Yogyakarta: Graha Ilmu. Kenehidie, Once. 1987. Shogakkou Kanji Shinjiten. Tokyo: Obunsha.

Koizumi, Tamotsu. 1994. Nihongo Kyoushi no Tame no Gengogaku Nyuumon. Tokyo: Daishuukan.

Kindiichi, Haruhiko. 2001. Nihongo no Tokushitsu. Tokyo, Nihon Housou Shuppansha Kyoukai.

Mitamura, Joyce Yumi \& Yasuko Kosaka Mitamura.1997. Let's learn kanji: an introduction to radicals, components and 250 very basic kanji. Tokyo: Kodansha International.

Renariah. 2004. Mengingat Kanji melalui Bushu. Jurnal FOKUS Jurusan Pendidikan Bahsa Asing FPBS UPI Vol. 1 No.2 Edisi April 2004.

Takebe, Yoshiaki. 1989. Kanji no Oshiekata. Tokyo: NAFL Aruku.

Tamamura, Fumio. 2001. Nihonggogaku wo Manabu Hito no Tame ni. Tokyo: Sekaishishousha.

Widiyanto, Joko 2012. SPSS For Windows. Surakarta: Badan Penerbit FKIP Universitas Muhammadiyah Surakata. 